\title{
Fragmented Politics in Hong Kong-Analyzing the Pro-democracy Cohesion in the Legislative Council Before 2019
}

\author{
Fung Chan $^{1}$ (ID
}

Received: 28 December 2020 / Accepted: 22 March 2021 / Published online: 8 April 2021

(c) The Author(s), under exclusive licence to Springer Nature B.V. 2021

\begin{abstract}
This study is to analyze how the fragmentation of the pro-democracy camp affected their council voting and policy stances before 2019. The quantitative measurements including the rice and unity indices are adopted to evaluate the cohesions of the proBeijing and pro-democracy camps in bill voting, in which the strategies employed by the pro-democracy camp are further analyzed. Before the 2010s, the moderate democrats deliberately separated from the administration and some of them also kept distance from the radical groups. However, since the radical ideologies gained supports from time to time, the moderate democrats had been forced to follow more pro-active lines against the administration. Although the political sphere of Hong Kong has drastically changed after the 2019 Anti-extradition Protests, the cohesion of the pro-democracy parties in the previous terms of the Legislative Council still facilitates to understand the legislative process in the city. In this article, 18 then members of the Legislative Council from different parties were interviewed in 2018, providing various insights on the analysis of pro-democracy cohesion and fragmented politics in Hong Kong.
\end{abstract}

Keywords Legislative Council of Hong Kong · Pro-democracy camp · Party cohesion $\cdot$ Filibuster $\cdot$ Democratization

\section{Introduction}

Both the pro-Beijing and pro-democracy camps were influencing the development of democratization in Hong Kong. Although the democratic development experienced setbacks in past decades, the trend of post-materialism had been emerged and the people could not be satisfied by only providing economic sweeteners [22].

Fung Chan

LCHA521@aucklanduni.ac.nz

1 School of Social Sciences, The University of Auckland, Auckland, New Zealand 
Francesch-Huidobro considered that the Hong Kong Government did not have the sense of urgency and political agenda to move public policies for future commitments under the current system [7]. The government was also incapable of implementing policies which would affect the interests of specific groups, since the institutional settings did not encourage the administration to suppress opposition or arouse supports [20]. As Oksanen noted, the democratization could be achieved through two possible solutions - the pro-establishment model, in which consensus would be reached in the society, and the wider democratic model, in which normative changes would be entailed in the political sphere [18]. The opposition simultaneously demanded a fundamental change of the political system and generated greater group movements through arousing the attention of the legitimacy crisis [19]. From the pro-democracy perspective, the Chinese authorities had broken the promise of the democratic system perceived by the SinoBritish Joint Declaration and the Basic Law, leading to the never-ending street protests and demonstrations against the illegitimate government in the 2010s [4, 6]. However, the pro-democracy camp was unwilling to make compromise with the Chinese authorities in the issue of political development.

Indeed, the moderate democrats were essential stakeholders to approve the political reforms [24], but the traditional sphere of pro-democracy camp was being encroached by the newly risen localist groups [9]. The democrats had fewer rooms for maintaining their moderate lines and needed to follow the new ideologies which were more aggressive and pro-active to change the political system. Apart from such paramount issue as the political reform, while the radicals usually opposed most government bills on social policies to show their hardlines towards the political settings, the moderate democrats on the contrary had more considerations of whether the aggressive opposition would affect the moderate and rational images. Before the 2019 Anti-Extradition Protests, the competitions between the moderate democrats and the radicals had been the important phenomena in the Legislative Council. Wang and Peng analyzed the party unity in the council, but the decision-making process within the two political camps is needed to have further investigation [23]. Moreover, even though the electoral settings may be largely changed by the Chinese authorities after March 2021 and the radicals may not be allowed to run the elections under the new administrative measures, the studies on the moderate democrats' practices in the council still enhance understandings on the development of the pro-democracy camp in the future.

In this article, the main research question is set as follows: "How does the (dis) unity of pro-democracy camp affect their council voting and policy stances before 2019?" There are 18 then members of Legislative Council interviewed in 2018 for providing insights on the interactions among pro-democracy parties and the governmental officials in the legislative process. Firstly, this article examines the unity of pro-democracy camp and its decision-making mechanism in the Legislative Council; secondly, it further explains why the camp had different degrees of unities on the government and member's motions; finally, it gives the reasons why it was difficult for the camp to make compromise with the administration on the paramount issues. 


\section{Rice and Unity Indices in the Legislative Council}

Current studies seldom analyze the cohesion of the two camps in the Legislative Council of Hong Kong with quantitative methods. The earliest measurement of party voting unity was developed by Stuart Rice, known as the rice score [21]. This score reflects the degrees of crossvoting in a party or a political bloc on a specific motion. However, since not all members in a legislature cast votes in every voting, the rice index, which just counts the numbers of "yes" and "no" votes, does not take nonvoting into consideration. As some members who oppose a motion do not want to cast "no" votes in order to prevent unnecessary attention, nonvoting on that motion would become an option. For the purpose of measuring the party cohesion in term of the proportion of party members, Carey proposed the unity score [1]. Both the rice and unity scores range from 1 to 0 , where 1 and 0 indicate perfect unity and perfect divide, respectively. The average of the rice and unity scores for different motions in a specific period is the rice and unity indices of the party or the political bloc (Table 1).

In this research, the cohesions of pro-democracy camps from the second to fifth terms (2002-2016) of the Legislative Council of Hong Kong are analyzed and both the government and member's motions are included. As for the sixth term (2016-2020), since the council during the period had experienced severe disruption and shut down due to the disqualification of legislators and the 2019 Anti-Extradition Protests, the records of voting in the sixth term are not included.

For the Legislative Council, not all motions are requested to have the completed records of members' voting (division). According to the article 47 of the "Rules of Procedure", "the president or chairman shall first call upon those members...to raise their hands" and "according to his judgment, state whether or not he thinks the required majority of the members present are in favor of the question". Any members present in the voting can challenge the president's judgement by claiming a division [15]. For most of the times, the members request to leave the records of voting on important motions. In a division, the members can choose five options of voting: "yes", "no", "abstain", "present" and "absent". Except "yes" and "no", the rest are seen as nonvoting.

In this research, all divisions (including amendments or bill readings) are included to analyze the cohesions inside the pro-democracy camps. If a voting has

Table 1 Conceptualization of rice and unity scores

Conceptualization

\begin{tabular}{|c|c|}
\hline $\begin{array}{l}\text { Rice score } \\
\operatorname{RICE}_{d t}=\frac{\left|\mathrm{Yes}_{d t}-\mathrm{No}_{d t}\right|}{\text { Vote }_{d t}} \\
\text { for party } d \text { on motion } t\end{array}$ & $\begin{array}{l}\text { Rice score measures party cohesion with "yes/no" votes only; a } \\
\text { higher score indicates higher cohesion }\end{array}$ \\
\hline $\begin{array}{l}\text { Unity score } \\
\text { UNITY }_{d t}=\frac{\left|\mathrm{Yes}_{d t}-\mathrm{No}_{d t}\right|}{\text { Member }_{d t}} \\
\text { for party } d \text { on motion } t\end{array}$ & $\begin{array}{l}\text { Unity score measures party cohesion with "yes/no" and "abstain/ } \\
\text { absent" votes; this is a discount of rice score depending on the } \\
\text { proportion of nonvoting; a higher score indicates higher cohesion }\end{array}$ \\
\hline Gap between rice and unity scores & $\begin{array}{l}\text { A wider gap between the two scores indicates a higher proportion of } \\
\text { party members who deliberately hide their stances with nonvoting }\end{array}$ \\
\hline
\end{tabular}


a record of division, the motion should be important to the legislator who claim the division. However, some legislators might use voting as a means of filibuster by proposing tremendous insignificant amendments. In order not to affect the data analysis, if there were more than 20 similar members' amendments to the specific bill, those members' motions would be excluded in the analysis. For example, in the review of the "Appropriation Bill 2014", several legislators moved 1192 amendments to the bill and claimed division for every amendment. As such, those members' amendments are excluded and only the bill readings proposed by the government are reserved in the analysis.

Moreover, there are two common types of voting methods in the council-the simple majority of the members present and the split voting system. While the former is used for the government's motions, the latter is used for the member's motions in which the passages are required simple majorities both from the geographical and functional groups. Since the split voting system is used for the member's motions, the cohesions of the geographical and functional groups are separated to analyze.

In Fig. 1, the rice and unity indices of pro-Beijing and pro-democracy camps across the four terms of the Legislative Council are shown. From the results, there are two important insights reflected from the data. Firstly, among the government motions, the pro-Beijing camp tended to have a stronger cohesion than the prodemocracy camp. One of the reasons is that the government officials had lobbying activities to ensure enough pro-Beijing votes to get the bills passed. Secondly, among the member's motions, the pro-democracy camp tended to have a stronger

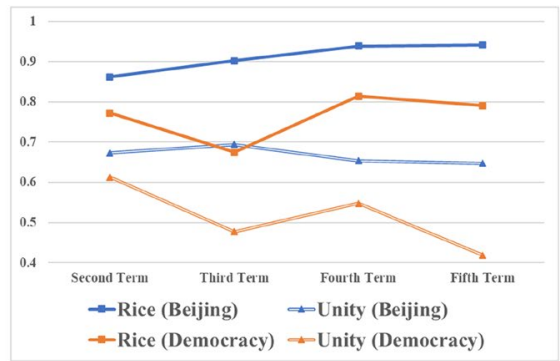

a

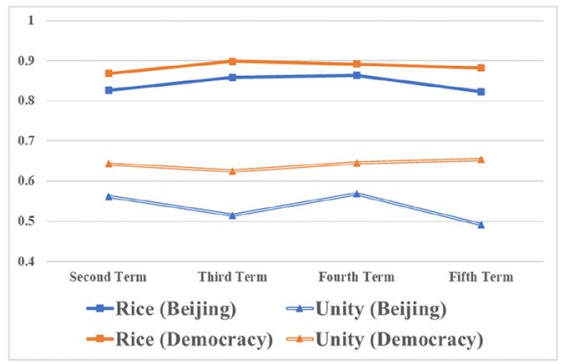

b

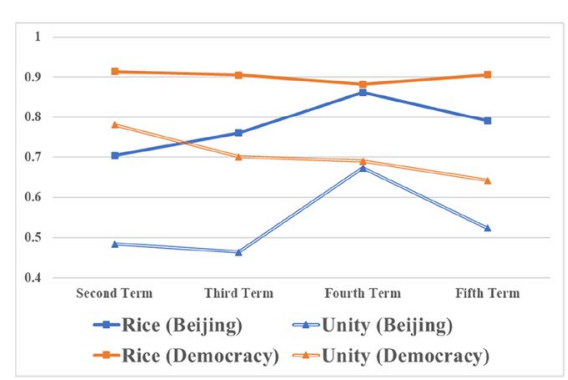

C

Fig. 1 a Rice and unity indices for government motion. b Rice and unity indices for member motion (geographical). c Rice and unity indices for member motion (functional) 
cohesion. Since proposing motions was also a means to enhance exposure, the prodemocracy legislators more frequently did this for expressing their unsatisfaction towards the government policies and their political viewpoints in the council. More details will be discussed in the later part of this article.

\section{Pro-democracy Blocs and Decision-making Mechanism}

Since the composition of pro-democracy camp in the Legislative Council was fragmented, there were no leading parties inside the camp to take up the position of leadership. Taking the sixth term of the Legislative Council as an example, the whole camp could be divided into four political blocs (Table 2). Each bloc was loosely formed by the legislators who were sharing similar policy ideologies and interests. The bloc leaders were just the representatives and might not have the powers to control their members, especially in the Professional Guild and the Council Front. ${ }^{1}$

Except for the summer recession of the council, the pro-democracy camp held meeting, known as the "Lunchbox Conference" or "Pro-Democracy Camp Meetings", on every Friday to share their viewpoints related to the matters of the council as well as the updated current affairs. The convenor of pro-democracy camp was Claudia Mo (Hong Kong First) in the 2018-2019 legislative year. The position was the nominal leader of the camp but did not contain any real powers. A pro-democracy legislator made a comment on the current system:

The 'Lunchbox Conference' is a very loose organisation in the council, and I always describe it as the 'Holy Roman Empire', which was formed by various multi-ethnic states. The conference should be a caucus of the pro-democracy camp, but we do not have any whips to enforce our decisions. Even though someone or any political blocs violate our consensus, there would not be any consequences on them. It, therefore, is just a platform to maintain mutual relationships and enhance understandings. ${ }^{2}$

Moreover, the conference did not include all oppositional members in the council. In the previous terms, the League of Social Democrats and the People Power did not participate in the conference, since most pro-democracy members considered that the radical stances applied by these two parties were not in line with them. In addition to some conflicts in the spheres of influence during electoral periods, the relationships among themselves had been frozen for a long time. In the sixth term of the Legislative Council, Cheng Chung-tai (Civic Passion), who inherited the political resource from Wong Yuk-man (People Power), did not participate in the conference. ${ }^{3}$ As such, the pro-democracy camp sometimes regarded themselves as the "non-establishment camp" (including all oppositional members) to differentiate the

\footnotetext{
1 Interview summary.

2 Interview summary.

3 Interview summary.
} 


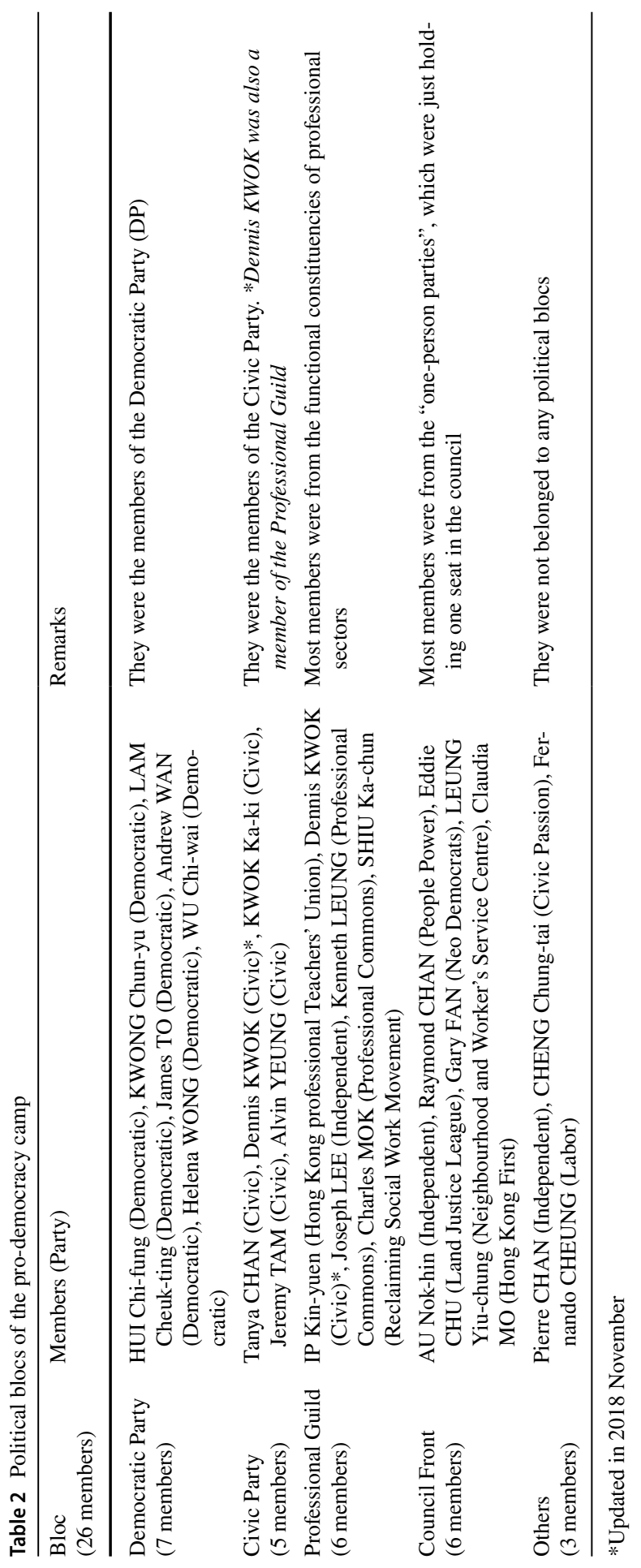


Table 3 Votes of "Medical Registration (Amendment) Bill 2016 - Second Reading" [13]

\begin{tabular}{|c|c|c|c|c|}
\hline & Democratic Party (6 votes) & Civil Party (6 votes) & Labor Party (4 votes) & Others (11 votes) \\
\hline Vote & Yes (6 votes) & $\begin{array}{l}\text { Yes (4 votes) } \\
\text { No (1 vote) } \\
\text { Abstain (1 vote) }\end{array}$ & Yes (4 votes) & $\begin{array}{l}\text { Yes ( } 2 \text { votes) } \\
\text { No ( } 6 \text { votes) } \\
\text { Abstain ( } 3 \text { votes) }\end{array}$ \\
\hline
\end{tabular}

narrow meaning of the pro-democracy camp (just including the members who join the conference).

Under such loose organization, the fragmented ideologies of the pro-democracy camp could be reflected by their stances on some social policies. One of the examples was the motion of "Medical Registration (Amendment) Bill 2016 - Second Reading", which was moved by the government in order to reform the Medical Council. The policy would enhance the protection of patient rights but undermining the interests of medical sectors. While the moderate democrats agreed to put the bill forward and the radicals directly opposed the policy, the Civic Party had three different stances in casting their votes (Table 3). The party's ambiguous stance on the policy led to serious criticisms from the pro-Beijing newspapers and medias [10]. This case was also from time to time quoted by the pro-Beijing side to describe how fragmented and inconsistent the pro-democracy camp was. From the view of proBeijing criticism, the pro-democracy members were deemed as the politicians who attempted to gain the benefits from both sides, ${ }^{4}$ despite the fact that the pro-Beijing camp had more fragmented representation.

\section{Pro-democracy Disunity on Government Motions}

After the handover, although the pro-democracy camp deliberately separated from the administration and was marginalized in the legislative process, the moderate democrats still had the dilemma over whether the government policies should be supported.

\section{Separating from the Administration}

The Chief Executive usually appointed the members of the Legislative Council and the public figures as the members of the Executive Council for the purpose of enhancing the executive-legislative relationship. During the colonial period, the unofficial members included the members both from the pro-Beijing and pro-democracy camps, such as Chow Liang Shuk-yee (later joined the Liberal Party), Wong Wang-fat (Pro-democracy Independent) and Tung Chee-hwa (later became the first Chief Executive). However, most of the figures from the pro-democracy camp were reluctant to accept the position after the handover, even though the Chief Executive

\footnotetext{
${ }^{4}$ Interview summary.
} 
attempted to invite the democratic side to join the Executive Council. In 2017, Carrie Lam, being the Chief Executive-elected, had approached the DP to seek one or two party members to be appointed into the Executive Council, ${ }^{5}$ but the party leader said that no party member could take up the top governmental positions before the implementation of the universal suffrage [4]. Such practice was due to the considerations of their political standpoints and the current behavioural restrictions on the members in the Executive Council.

In accordance with the Oaths and Declarations Ordinance (Cap. 11), the members of the Executive Council should take the Oath of Fidelity after his/her appointment and promise not to reveal any matters being discussed in the council. The aim of this principle was to ensure that the members could speak freely without any fears and pressure, so as to facilitate the Chief Executive to receive prompt and objective advices in the policy making process. Moreover, the conclusions made by the Executive Council were usually presented as collective decisions, regardless of the discussion process on specific issues. However, the members of the Executive Council were still allowed to establish the "agree to disagree" process, and the members, if being the members of the Legislative Council simultaneously, would not be necessary to follow the collective decision to vote in the legislature. ${ }^{6}$ Still, this did not remove the worries of the pro-democracy camp and one of the legislators from a pro-democracy party made the following comments:

Even though one of our party members is appointed as the members of the Executive Council, the party would not be a part of coalition government. In other countries or regions, ruling power can be shared by the smaller parties in a coalition, in which the parties have bargaining strength to influence policies. Once the smaller parties withdraw from the coalition, the largest party would not have enough seats to form the government. However, in Hong Kong, the figures, representing political parties and sitting in the Executive Council, just serve an advisory role in the policy making process. Even though you threaten the government to quit the position, the Chief Executive would not change his/ her mind on the big issues in order to entertain your party. ${ }^{7}$

The legislator further explains the consequence of being appointed into the Executive Council:

Due to the principles of confidentiality and collective responsibility, the party member in the Executive Council should abide by the decision made with the government. If the member is a legislator, he/she may need to inform our caucus not to follow the party line. Imagining that one party just holds 5 or 6 seats in the council, losing one vote may undermine our influence in a large extent. Of course, the member can request the Executive Council to "agree to disagree" on some particular issues. However, he/she cannot expose what he has

\footnotetext{
5 Interview summary.

${ }^{6}$ Interview summary.

${ }^{7}$ Interview summary.
} 
discussed in the council, while some people criticize why the member cannot persuade the Chief Executive to change the policies. Some even accuse the member of colluding with the officials, placing he/she or the whole party into an embarrassing situation. ${ }^{8}$

Moreover, the pro-democracy figures did not have much interest in taking the politically appointed positions in the policy bureaus. Since the political officials were requested to maintain political neutrality, those pro-democracy figures needed to withdraw from their parties before accepting appointments. The pro-democracy legislators would not consider those officials as a part of the pro-democracy camp anymore. For example, Fung Wai-kwong was a DP member, but he quitted the party before being appointed as the Information Coordinator in the Chief Executive Office. Since then, Fung had become well-known for his pro-government viewpoints and the hostile relationship with the pro-democracy camp. ${ }^{9}$ Under the pro-democracy logic, the politically appointed officials, who originally had party memberships, were impossible to achieve dual accountabilities. As such, even though the pro-democracy figures were appointed as the top officials, it was difficult for them to serve as the communication agents for the purpose of enhancing the executivelegislative relationship.

As one of the pro-Beijing legislators asserted, the Hong Kong Government and the Chinese authorities would like to invite more moderate democratic figures into the administrative structures. With the concept of the "united front", some prodemocracy figures had become the targets to be united under the front established by the Chinese departments addressing the Hong Kong affairs in recent years. Unlike the early stage of the handover, the DP and other moderate democrats were regarded as the main opposition of the government or the "reactionary" forces to the Chinese Communist regime. ${ }^{10}$ Appointing those figures as the top governmental positions did facilitate to absorb the public voices represented by the pro-democracy parties and follows the principle of "administrative absorption of politics". However, most of pro-democracy members rejected to be united due to their party loyalties or political considerations. Without the participation of pro-democracy camp, the government might not promptly gauge public views and secure a broader support base. As a result, the policies proposed by the administration might tilt heavily towards the pro-Beijing interests.

\section{Being Marginalized in the Legislative Process}

The existence of functional constituencies guaranteed the pro-Beijing majority in the Legislative Council. In other words, the pro-democracy camp was the "permanent" opposition and there must not be any rotations of ruling coalition. Even though the pro-democracy camp had the most ideal performance in the elections,

\footnotetext{
8 Interview summary.

9 Interview summary.

${ }^{10}$ Interview summary.
} 
it was still difficult for the camp to get over 35 seats (simple majority) in the council. In Table 4, since most of the functional constituencies contained the pro-Beijing or pro-business features, the pro-democracy figures were nearly impossible to win the seats through those constituencies. ${ }^{11}$ Only the constituencies representing the professional practitioners, such as education, legal and medical, could be won by pro-democracy side. In those professional sectors, the corporate voters did not have much influence as in other constituencies and the individual voters usually outnumbered the corporate ones. Simply put, the highest number of seats in the functional constituencies possibly taken by the pro-democracy camp is just 10 (the number was 8 at the end of 2018). As for the geographical constituencies, with the system of proportional representation, the ratio of popular votes obtained by the pro-democracy camp had maintained about $60 \%$ since the handover. Given that there was no efficient coordination mechanism among the pro-democracy parties, the maximum number of seats which could be obtained by the pro-democracy camp was around 30. In sum, the democrats were unable to obtain over half of the seats in the council under the electoral settings.

As the "permanent" opposition, the pro-democracy camp did not have veto power on any governmental policies. As the government did not rely on any pro-democracy votes to have the policies or bills passed, the officials sometime might lobby supports only from the pro-Beijing members. A pro-democracy legislator pointed out the difference of the officials' altitudes before and after the handover:

Before 1997, even though the pro-democracy camp did not hold over a half of the seats in the Legislative Council, the officials at least respected the members from our side. They understood that we were the people's representatives having public mandates and actively invited us to express opinions on various issues. The political neutrality could be maintained by the officials at the time. However, the supervisors of the policy bureaus had become politically appointed in the $2000 \mathrm{~s}$, leading to more bias over the pro-democracy camp. The officials, including the permanent secretaries who are supposed not to have any political stances, usually assume that we will not support their policies and become reluctant to lobby our supports. As such, more mistrust has been developed between the pro-democracy camp and the administration. ${ }^{12}$

\section{Dilemma over the Government Policies}

Although the pro-democracy camp did not have any ruling power and was difficult to persuade the administration to change the policies proposed, the pro-democracy camp did not always cast their votes against the administration. In Fig. 1a, the rice and unity indices show that the pro-democracy camp had lower cohesions than the pro-Beijing camp on government motions from the second to fifth terms of the Legislative Council. It reflects that some pro-democracy legislators supported the government motions while some opposed. For example, on 13 May 2016, the council voted on the motion

$\begin{array}{ll}11 & \text { Interview summary. } \\ 12 & \text { Interview summary. }\end{array}$ 


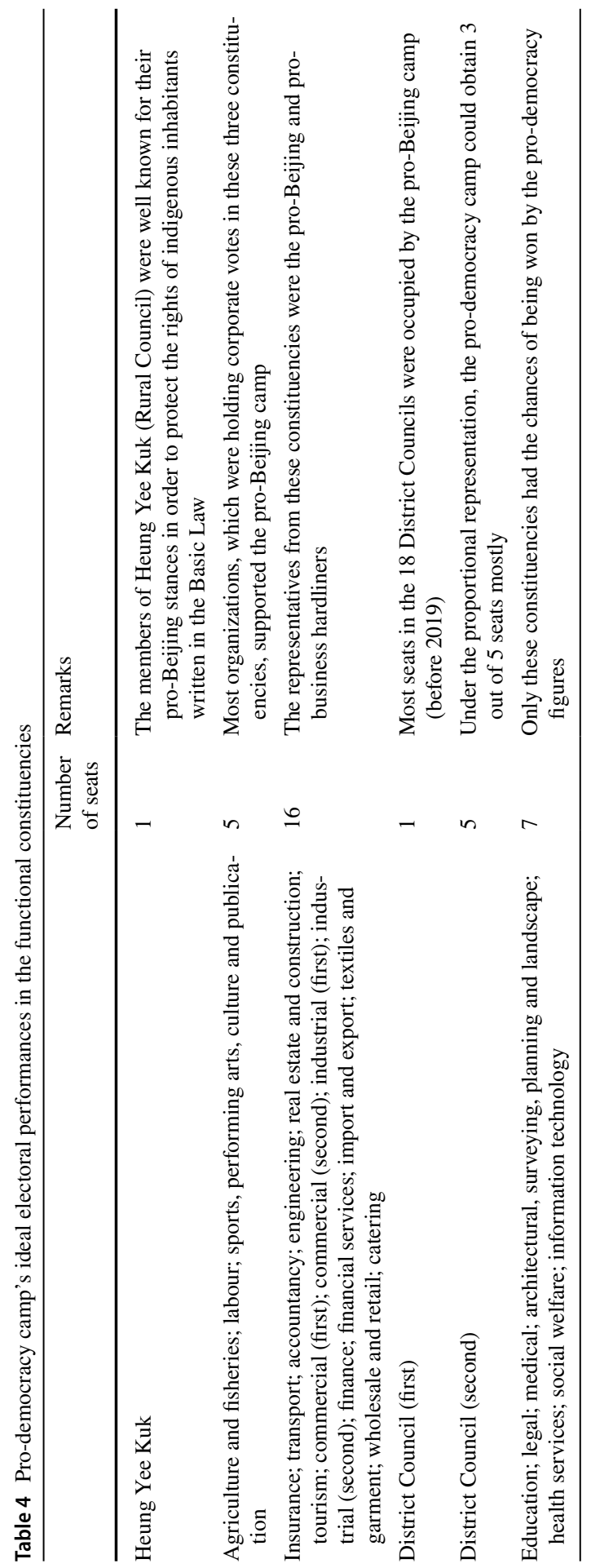


Table 5 Votes of "Appropriation Bill 2016 - Third Reading" [14]

\begin{tabular}{llllll}
\hline & $\begin{array}{l}\text { Democratic Party } \\
(6 \text { votes })\end{array}$ & $\begin{array}{l}\text { Civil Party (6 } \\
\text { votes })\end{array}$ & $\begin{array}{l}\text { Labor Party (4 } \\
\text { votes })\end{array}$ & $\begin{array}{l}\text { Professional } \\
\text { Guild (3 votes) }\end{array}$ & Others (8 votes) \\
\hline Vote & Yes & No & No & Yes & No \\
\hline
\end{tabular}

of "Appropriation Bill 2016 - Third Reading" (government motion), in which the DP and the Professional Guild agreed to pass the bill but the Civil Party, the Labor Party and others including the radical legislators casted "no" votes (Table 5).

The moderate democrats explained the reasons why they could not reject the government motions in most cases:

The moderate democrats, especially the DP members, need to make a balance between the public voices and the practical situation. If they disagree to some constructive policies proposed by the administration, the pro-Beijing camp may attack the moderate democrats on the issues. Since their supporters are from moderate voters, rejecting most of the bills irrationally cannot arouse the supports. Also, the moderate democrats establish their community base and stand in the district council elections. At the community level, the moderate democrats are more vulnerable to be criticized as trouble-makers by the pro-Beijing camp. ${ }^{13}$

However, the radical groups in the council usually aroused the moderate democrats to have further actions to block the government motions. The radical groups considered that the pro-democracy camp should have a clear-cut stand against the government. Even if most pro-democracy legislators cast "no" votes on the government motions, the bills were also passed due to the pro-Beijing majority in the council. The policy outcomes were indifferent, while the pro-democracy camp expressed its dissatisfaction towards the institutional system through such political gesture. Looking at Fig. 1a again, the gap between two indices had been becoming wider for the pro-democracy camp. The value difference of the two indices increased from 0.198 in the third term to 0.372 in the fifth term. This reflects that more pro-democracy legislators chose to abstain votes or have no actions to show their stances towards the government motions.

The radical groups also preferred initiating filibuster to delay policy deliberation or strive for higher demands. On one hand, the senior members of the moderate democrats deliberately separated with those radical groups and took an in-between line to maximize their supports. On another hand, the young members from the moderate parties more likely employed filibuster than the senior members. Due to the restrictions of party discipline, the young members usually did this in a low-profile way, known as "hidden filibuster". The members delayed the time of policy deliberation through increasing their floors and attempting to get more detailed information from the government departments. ${ }^{14}$ All in all, marginalizing the pro-democracy legislators in the legislative process caused mistrust between the administration and the pro-democracy camp, leading to a worsening executive-legislative relationship in the council.

\footnotetext{
13 Interview summary.

14 Interview summary.
} 


\section{Pro-democracy Unity on Member's Motions}

As mentioned before, the number of member's motions moved by the pro-democracy camp was higher than the pro-Beijing camp, even though the latter occupied the majority of seats in the council. On one hand, the pro-democracy legislators moved amendments or motions to arouse attention from the public. On another hand, since the government usually consulted the pro-Beijing camp before tabling the bills in the council, the pro-Beijing camp legislators seldom required to move amendments to the government bills. In recent years, due to the rise of filibuster launched by the radical legislators, the pro-Beijing legislators preferred not to move any motions in order to save the time of council sessions. ${ }^{15}$ In Fig. $1 b$ and c, the pro-democracy cohesions on the member's bills are also higher than the pro-Beijing camp. These will be explained from the perspectives of ideology and the motives behind the motions.

\section{More Fragmented Representation for the Pro-Beijing Camp}

Comparing with the ideologies, the pro-democracy camp was usually more united than the pro-Beijing camp. Although the pro-Beijing camp contained higher cohesions in the government bills as shown in Fig. 1, the reasons for such unity were due to the lobbying activities from the government officials. This does not imply that the pro-Beijing legislators shared similar ideologies to support the government policies. As for the member's bills, the officials had lower interest in those motions which would not affect the government policies and would not influence their performance assessment of those civil servants. ${ }^{16}$ The pro-Beijing legislators had more flexibility to choose to agree or oppose the motions proposed by other members. In Fig. 1b and $\mathrm{c}$, the data shows that the pro-democracy camp had higher cohesions on the member's bills from the second to fifth terms, reflecting that the camp shared more similar stances on social policies.

Taking the motion proposed by the Social Welfare functional constituency legislator Cheung Kwok-che in 2012, he moved a member's bill to urge the government to legislate for the regulation of working hours. The content proposed in this motion was deemed to undermine the interests of business sectors and would increase the cost of operation for the employers. As such, it was not difficult to understand why the legislators from the functional constituencies representing the business sectors opposed to legislate for the working hours regulation. Even though the DAB contained the members returned by the geographical constituencies, those also followed their party members from the business sectors to choose "abstain" or to be absent from the voting. On the contrary, the FTU and the FLU contained three seats returned by the Labour functional constituency and represented the labour unions and the employees' interests. Among the pro-Beijing parties, only these two parties

$\begin{array}{ll}15 & \text { Interview summary. } \\ 16 & \text { Interview summary. }\end{array}$ 
supported the motion of working hours which enhanced the protection of labour right. From Table 6, the fragmented ideologies of pro-Beijing camp are shown in the votes of the motion.

As for the pro-democracy camp, nearly all members supported the motions of the working hours regulation. Most of them shared the pro-employee stances and have narrow differences in economic and social policies. Unlike the government motions, the radicals required to show their political gestures to oppose the government deemed as illegitimate from the views of their supporters. This explains the reasons why the pro-democracy camp had higher cohesions on the member's motions than the pro-Beijing camp.

\section{More Incentives of Embarrassing the Administration for Gaining Supports}

Since various pro-democracy parties stood in the Legislative Council elections, the political figures elected usually represent a narrow range of political spectrum and there were only small rooms for them to change their political or policy viewpoints. The radical groups must go beyond the traditional resistance methods to gain the supports. In recent years, embarrassing the administration in the legislative process was one of the ways to arouse public attention. The citizens who supported the prodemocracy camp also expected that the council served the role of watchdog over the government. While the pro-democracy legislators could move member's bills

Table 6 Votes of motion on "Legislating for the Regulation of Working Hours" [12]

\begin{tabular}{lc}
\hline Pro-democracy camp & Pro-Beijing camp \\
\hline Democratic Party (6 votes) & FTU/ FLU (7 votes) \\
Yes (6 votes) & Yes (7 votes) \\
Civil Party (6 Votes) & DAB (12 votes) \\
Yes (5 votes) & Abstain (9 votes) \\
Absent (1 vote) & Absent (3 votes) \\
Labor Party (4 votes) & BPA (7 votes) \\
Yes (4 votes) & No (5 votes) \\
Others (11 votes) & Abstain (1 vote) \\
Yes (10 votes) & Absent (1 vote) \\
Absent (1 vote) & LP (5 votes) \\
& No (4 votes) \\
Rice score: 1 & Absent (1 vote) \\
Unity score: 0.93 & Others (10 votes) \\
\hline
\end{tabular}

FTU Hong Kong Federation of Trade Unions, FLU The Federation of Hong Kong and Kowloon Labour Unions, $D A B$ Democratic Alliance for the Betterment and Progress of Hong Kong, BPA Business and Professionals Alliance for Hong Kong, $L P$ Liberal Party 
to embarrass the administration, the whole camp tended to support such types of motions without much consideration.

One of the typical examples was that the pro-democracy camps invoked the "Legislative Council (Powers and Privileges) Ordinance (Cap. 382) (P\&P Ordinance)" to investigate the governmental scandals. The P\&P Ordinance provided powers and privileges to the legislators to discharge the functions of the council and safeguard the dignity of the legislature. Section 9 of the ordinance specifically empowered the council or a standing committee to order attendance of witnesses. The council could also confer the power to a selected committee to investigate any issues related to public interests. If the witnesses being ordered to testify before the council disobeyed the orders (e.g. not attending, not providing requested documents, giving false statements, or refusing to answer question put by the council), such behaviors would constitute a criminal offence. The offender was liable to a fine of 10,000 HKD and to imprisonment for 12 months [8]. As such, the P\&P Ordinance was regarded as the "imperial sword (granted arbitrary by the 'emperor')" of the Legislative Council.

After the 1997 handover, the P\&P Ordinance had been invoked to order witnesses to testify the issues addressing the great public interests, such as the chaotic situation during the commencement of the new international airport (1998) and the crisis management problems of handling the Severe Acute Respiratory Syndrome (2003). However, since the fifth term of the Legislative Council (2012-2016), although the pro-Beijing camp had complained that the pro-democracy camp abused the P\&P Ordinance in order to enhance their media exposure, ${ }^{17}$ some of them sometime supported the investigative motions. Table 7 shows the motions moved by the prodemocracy legislators to invoke the P\&P Ordinance in the 2012-2013 legislative.

Apart from the invoking of the P\&P Ordinance, the legislators could also express their paramount viewpoints through submitting petition or moving the motion on no-confidence in the Chief Executive, other officials, or the whole administration. Since over half of the member's motions was moved by the pro-democracy legislators, their allies tended to support what the legislators from the same camp supported. Such practices further elaborate the phenomenon as shown in Fig. 1b and c, in which the rice and unity indices were higher among the pro-democracy legislators both in the geographical and functional groups.

\section{Cost of Making Compromise with the Administration on Paramount Issues}

The motions of paramount issues needed the two-thirds majority of the legislators in the council to be passed. In the past, the pro-democracy camp still held the veto power tightly and the administration must seek their supports in order to pass the paramount issues. However, that the pro-democracy camp made compromise with the administration on those issues could be risky and not conducive to arousing more supports. Under the institutional settings, the government was also difficult

17 Interview summary. 


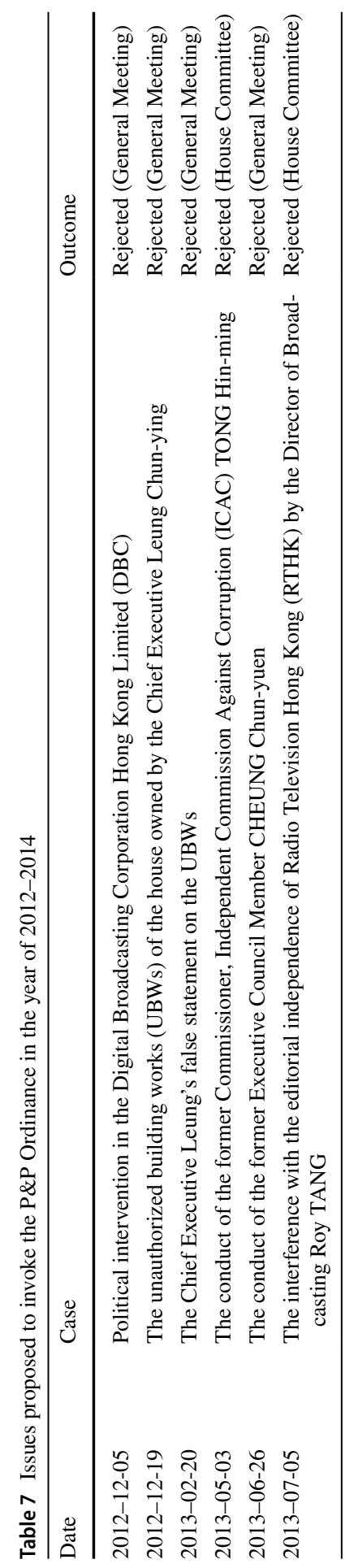


to share power with the pro-democracy camp. Even though some democrats were willing to make such compromise, nothing or few benefits from the administration could be obtained. Some legislators maintained that the 2000 s may be the decade that the pro-democracy camp was more possible to have negotiation with the administration. ${ }^{18}$ After the turn of the 2010s, more radical groups arose to have seats in the council and the pro-democracy voters were not necessary to support the DP as well as other moderate democrats. As a result, there were fewer rooms for making compromise with the administration than before.

Since the handover, five paramount motions had been proposed by the administration to address the political reform packages in 2005, 2010 and 2015. The package in 2010 was the only one in which compromise was made, while another two were not supported by over two-thirds majority of the council. However, the moderate democrats were seriously criticized to accept the 2010 Political Reform Package by other groups in the camp, leading to a change of the political strategies employed by the moderate democrats in the later period. In 2010, the administration introduced the political reform package, in which the number of Election Committee members and legislative councilors increased from 800 to 1200 and from 60 to 70, respectively. Among those ten newly established seats in the Legislative Council, five seats would be returned by the geographical constituencies and another five seats would be elected from among the district councilors (not including the appointed members). The whole pro-democracy initially opposed the package, since what they were demanding was the immediate implementation of "genuine universal suffrage". In 2007, the National People's Congress Standing Committee (NPCSC) made a decision that the earliest times of the implementation of the universal suffrage for the Chief Executive and the Legislative Council would be 2017 and 2020, respectively [5]. The 2010 Political Reform Package just addressed the electoral methods of selecting the Chief Executive and forming the Legislative Council in 2012.

Later, the DP initiated a negotiation with the Chinese authorities in the final stage of the package's scrutiny. The DP leaders met Li Gang, the deputy director of the LOCPG in Hong Kong, at the liaison office headquarters. While the Chinese side praised that the DP was willing to communicate to contribute to the constitutional development in Hong Kong [16], other pro-democracy parties condemned that the DP betrayed the democratic movement. The DP proposed that the five new functional seats would be elected by the voters who were not belonged to any functional groups. In this way, over 3 million voters could get two votes in their hands (geographical and functional constituencies). The administration moved the amendments to the original package, and later the final bills were passed with the supports of the DP and the ADPL. One of the DP legislators explained why the party needed to make such a decision:

We understood that Beijing was also one of the stakeholders in the development of the democratic system in Hong Kong, and the NPCSC was the high-

18 Interview summary. 
est authority in the whole process of decision-making. We could not ignore that the NPCSC only allowed the implementation of universal suffrage after 2017. What we were fighting for was the best options of the two elections in 2012. The DP also attempted to ensure that Beijing could fulfill its promises on the Hong Kong's democracy. Through making compromise, we hoped that the relationship between the pro-democracy camp and the central government could be improved. ${ }^{19}$

However, other pro-democracy considered that the DP just hoped to retake its status of leadership in the pro-democracy camp. Before the release of the 2010 Political Reform Package, there were five legislators from the Civic Party and the League of Social Democrats resigning from the Legislative Council in 2009. The resignation initiated the by-elections in five constituencies, known as the "Five Constituencies Referendum". The referendum granted the voters an opportunity to show their determination of achieving the universal suffrage. Without a doubt, the DP was marginalized in these democratic campaigns and needed to search a way to outstand itself. A pro-democracy legislator made a comment on that:

The DP just wanted to establish the image as a kingmaker in 2010, but the party was walking on a wrong way and its proposal undermined the solidarity of the whole pro-democracy camp. Unfortunately, the DP had become the socalled 'leftist idiot (zuojiao)'. Furthermore, the new proposal also provided the DP an advantageous environment to win more seats in the Legislative Council. More than 15 district councilors were needed to nominate a candidate in the new function constituency. The DP could stand at least two candidates in the elections and get two more seats under the proportional representation. Due to these two seats, the DP were walking further and further away from other prodemocracy parties. ${ }^{20}$

The reason why the 2010 Political Reform Package was the watershed of the democratic development was that the tension between the moderate democrats and the radical groups had come out into the open since then. The People Power, which was a radical organization established in 2011, committed itself to undermining the DP and other moderate democrats. In the 2011 District Council Election, the People Power candidates stood in the constituencies in which the DP also stood. With the system of first-past-the-post, the DP vote bases were divided, leading to losing in the elections. While the number of DP supporters dropped, the pro-Beijing candidates were benefited. In the 2012 Legislative Council Election, even though the DP got two seats from the new functional constituency, the performance in the geographical constituencies were not good as expected. More pro-democracy voters supported other parties, such as the Civic Party, instead of the DP. Simply put, it was concluded that the DP could not be benefited in making compromise with the Chinese authorities.

\footnotetext{
19 Interview summary.

${ }^{20}$ Interview summary.
} 
Until 2014, the NPCSC promulgated the "831 Decision", in which it ruled that Hong Kong could implement the universal suffrage for the Chief Executive, given that the candidates shall be nominated by a nomination committee which should be formed under the structure of the previous Election Committee. The decision later triggered off the Occupy Central, but the mass movement could not make the central government to withdraw the decision. The Hong Kong Government proposed the 2015 Political Reform Package under the framework of the "831 Decision". The package granted the Hong Kong people to cast their votes with the "one man, one vote" principle, but the candidates standing in the election shall be selected by the nomination committee before starting their campaigns. The pro-democracy parties had a hard line to oppose the government proposal, but some of them were still afraid of the DP accepting the package. A pro-democracy legislator pointed out that:

Once the administration released the version of the 2015 Political Reform Package, some 'leftist idiots' from the DP took the proposal into the consideration. They believed that the moderate democrats could be granted by the nomination committee to stand in the election. Once there would be a prodemocracy candidate running in the election employing the universal suffrage, the pro-democracy camp would get the ruling power. However, with the previous experience, we expected that the universal suffrage could be implemented in the 2000s, but what can we get from the Basic $\mathrm{Law}^{21}$ ?

The influence of the moderate democrats became weaker in recent years, leading to fewer rooms for making compromise with the administration on the paramount issues, especially for the political reforms. After the failure in 2015, the following Chief Executive election employed the original method to select the top leader [2]. While the Chinese authorities did not trust the pro-democracy camp, the radical groups aroused more supports from the Hong Kong people and eroded the vote bases from the DP and other moderate democrats. On the one hand, if somebody in the pro-democracy camp attempted to initiate negotiations with the Chinese authorities under the framework of the "831 Decision", those political figures will be considered traitors to the democratic movement. On the other hand, if the moderate democrats united with the radical groups, the Chinese authorities would have fewer chances to withdraw the decision. The fragmentation of pro-democracy camp made the situation become much more complicated and establish a political gridlock.

Such development of pro-democracy camp also explains why there were no moderate democrats having communication with the Chinese authorities during the 2019 Anti-Extradition Protests, which later caused the total shutdown of the Legislative Council in the 2019-2020 legislative year. Since no pro-democracy parties showed their softer sides, such circumstance paved the ways for the Chinese authorities to change the policy towards Hong Kong and become more authoritarian to tackle the local issues after a series of riots in the city.

21 Interview summary. 


\section{Concluding Remarks}

Lees-Marshment proposed several models to analyze the political marketing employed by political parties [11]. For example, a product-oriented party (POP) is the traditional party establishing their party lines without having much attention on voter's response, while a market-oriented party (MOP) is the party designing their viewpoints after conducting thorough market research. The nature of the DP in Hong Kong had been transformed from the POP to MOP. Before the handover, the DP had the leadership among the pro-democracy groups and supported the "one country, two systems". The party attempted to maintain a good relationship with the Chinese authorities, although various measures, including the abolition of the municipal councils and the implementation of proportional representation, were taken by the government to prevent the DP from the further development. With this mindset, the DP believed that the moderate line could arouse the moderate voters which formed the largest base in the population. This was one of the reasons why the DP was confident to make a deal with the Chinese authorities in 2010. However, when the supporters shifted to support the other pro-democracy parties, the DP was forced to change itself to be a MOP. While the DP became more willing to engage in filibuster in the council, it also attempted to be more in line with other pro-democracy parties.

This study analyzes the interactions among the pro-democracy parties and the administration in the Legislative Council. As Ma noted, the democrats started to divide due to the rise of radical voices in the political sphere [17]. In the beginning, the moderate democrats attempted to separate from the radical groups in order to maintain their rational image, but in recent years, the democrats had more cooperation with the radicals and were willing to engage in filibuster. It made the Hong Kong Government more difficult to introduce the social policies which could improve the people's livelihoods. The radicalization of moderate democrats also made the Chinese authorities employ the authoritarian policies over Hong Kong after a series of riots in 2019.

Although this study does not analyze the most updated situation and the Chinese new authoritarian policies towards Hong Kong, it still provides the circumstance in the 2010s and employs the quantitative method to examine the cohesion of pro-democracy camp. It is concluded that while the ideologies inside the pro-democracy camp are more untied than the pro-Beijing camp, the pro-democracy legislators had fewer rooms to make compromise with the administration, leading to an abnormal executive-legislative relationship before 2019. After the implementation of the Hong Kong National Security Law and the National People's Congress decision on reforming the Hong Kong's electoral system, there will be only small rooms left for the pro-democracy camp to develop. While the radicals who do not recognize the Basic Law will not be allowed to stand in the elections, the number of seats which the moderate democrats have chances to obtain will drastically decrease. Although the fate of pro-democracy camp is unknown at this moment, the practices of moderate democrats in the previous terms of the council provide different insights to predict what the pro-democracy members can do or will do in the future Legislative Council formed by the reformed electoral systems. It is still noteworthy for the researchers to study the past development of pro-democracy camp. 


\section{References}

1. Carey, J. M. (2008). Legislative Voting and Accountability. Cambridge University Press.

2. Chan, F., \& Sun, B. (2019). Digital Representation in an Electoral Campaign Influenced by Mainland China: The 2017 Hong Kong Chief Executive Election. Issues \& Studies, 55(02), pp1950005.

3. Cheng, E. W. (2016). Street Politics in a Hybrid Regime: The Diffusion of Political Activism in Postcolonial Hong Kong. The China Quarterly, 226, pp383-406.

4. Chung, K. (2017). Bernard Chan 'to be Convenor' of New Cabinet. South China Morning Post (2017-0328), pEDT4

5. Constitutional and Mainland Affairs Bureau (2009). Methods for Selecting the Chief Executive and for Forming the Legislative Council in 2012 - Public Consultation. <https://www.legco.gov.hk/yr09-10/ english/panels/ca/papers/ca1126-cppr091118-e.pdf>. Accessed 1 Mar 2021

6. Davis, M. C. (2015). Beijing's Broken Promises. Journal of Democracy, 26(2), pp101-110.

7. Francesch-Huidobro, M. (2012). Institutional Deficit and Lack of Legitimacy: The Challenges of Climate Change Governance in Hong Kong. Environmental Politics, 21(5), pp791-810.

8. Hong Kong e-Legislation (2017). Cap. 382 Legislative Council (Powers and Privileges) Ordinance. $<$ https://www.elegislation.gov.hk/hk/cap382>. Accessed 1 Mar 2021

9. Kaeding, M. P. (2017). The Rise of "Localism" in Hong Kong. Journal of Democracy, 28(1), pp157-171.

10. Law, D. (2016). Civil Party should be Shameful for its Ambiguous Stances on Medical Reform (Yigai Sanbian Xiazhu Songdang Luobao). Wen Wei Po (2016-07-09), A10.

11. Lees-Marshment, J. (2014). Political Market Research. IN Lees-Marshment, J. (ed.). Political Marketing: Principles and Applications. Routledge.

12. Legislative Council (2012). Motion on "Legislating for the Regulation of Working Hours". <https:// www.legco.gov.hk/yr12-13/chinese/counmtg/voting/v20121017.pdf>. Accessed 1 Mar 2021

13. Legislative Council (2016a). Medical Registration (Amendment) Bill 2016 - Second Reading. <https:// www.legco.gov.hk/yr15-16/chinese/counmtg/voting/v20160706.pdf>. Accessed 1 Mar 2021

14. Legislative Council (2016b). Appropriation Bill 2016 - Third Reading. <https://www.legco.gov.hk/ yr15-16/chinese/counmtg/voting/v20160511.pdf>. Accessed 1 Mar 2021

15. Legislative Council (2019). Rules of Procedure of the Legislative Council. <https://www.legco.gov.hk/ general/english/procedur/content/rop.pdf>. Accessed 1 Mar 2021

16. Li, J., \& Guo, J. (2010). Central Government, DP Hold Historic HK Meeting. China Daily Hong Kong Edition (2010-05-25), pH01.

17. Ma, N. (2011). Hong Kong's Democrats Divide. Journal of Democracy, 22(1), pp54-67.

18. Oksanen, K. (2011). Framing the Democracy Debate in Hong Kong. Journal of Contemporary China, 20(70), pp479-497.

19. Ortmann, S. (2010). Opposition and Regime Legitimacy. Journal of Asian and African Studies, 45(1), pp67-86.

20. Ramesh, M. (2012). Health Care Reform in Hong Kong: The Politics of Liberal Non-Democracy. The Pacific Review, 25(4), pp455-471.

21. Rice, S. A. (1925). The Behavior of Legislative Groups: A Method of Measurement. Political Science Quarterly, 40(1), pp60-72.

22. Sing, M. (2010). Explaining Mass Support for Democracy in Hong Kong. Democratization, 17(1), pp175-205.

23. Wang, Y., \& Peng, M. (2015). Party Unity after Elections: A Study of the Roll-Call Votes in Hong Kong's Legislative Council. Politics, 36(2), pp169-179.

24. Zhang, B. (2010). Beijing's 2007 Political Reform Plan and Prospects for Hong Kong's Democratization. Democratization, 17(3), pp442-464.

Publisher's Note Springer Nature remains neutral with regard to jurisdictional claims in published maps and institutional affiliations. 